\title{
Dialog dalam Resolusi Konflik-Interaktif
}

\author{
I Nyoman Sudira \\ Jurusan Ilmu Hubungan Internasional, Universitas Katolik Parahyangan \\ E-mail: belinyomanbagus@yahoo.com
}

\begin{abstract}
Abstrak
Komunikasi merupakan hal yang penting dalam kegiatan apapun. Dalam kerjasama bahkan konflik membutuhkan komunikasi. Akan tetapi, komunikasi juga dapat menjadi sumber masalah apabila informasi yang disampaikan tidak diterima dan dipahami dengan baik. Banyak faktor yang dapat menghambat terjalinnya komunikasi dengan baik. Sesungguhnya, komunikasi dapat menjadi salah satu cara dalam melakukan resolusi konflik Tulisan ini akan menjelaskan dua pokok bahasan yang nantinya akan mendeskripsikan posisi dan peran dialog dalam meretas jalan perdamaian dengan studi kasus di Papua. Bagian awal dari tulisan ini memprioritaskan pembahasan pencarian pemahaman yang komprehensif mengenai dialog. Kemudian pada bagian kedua pembahasan akan difokuskan pada keterkaitan dialog dengan Resolusi Konflik-Interaktif (RKI).
\end{abstract}

Kata Kunci: dialog, resolusi konflik-interaktif

\begin{abstract}
Communication is important in any activities. In cooperation even conflict are needs communication. However, Communication can be source of problem if the information not stated and understanding well. In fact, communication is an alternative way for conflict resolution. This paper will explain two main discussion which later will describe position and role of dialogue paved into peace with Papuas as the study case. First part of this paper will prioritized the discussion about dialogue comprehensive understanding. In the second part this discussion will focused on the relations between dialogue and Interactive-Conflict Resolutions.
\end{abstract}

Keywords: dialogue, interactive-conflict resolutions

Komunikasi apapun bentuknya (dialog, perdebatan, dan percakapan), membuka terjalinnya proses pencarian, pengekspresian pemikiran dan perasaan yang dilakukan antara dua orang tau lebih. Apapun konteks hubungan antar manusia: kerjasama, persaingan bahkan dalam suasana berkonflik pasti membutuhkan komunikasi.

Komunikasi mengandung nilai yang begitu kental yakni seperangkat prosedur dimana suatu perasaan akan mempengaruhi perasaan yang lainnya. ${ }^{1}$ Ini mengindikasikan bahwa komunikasi tidak saja terjadi secara lisan, tertulis, melalui media masa, tapi juga bisa melalui musik, teater, dan dalam semua perilaku manusia. Pemikiran diatas menegaskan bahwa komunikasi adalah sebuah proses yang melibatkan terjadinya transmisi dari perasaan pengirim (Komunikator) terhadap penerima

\footnotetext{
${ }^{1}$ Shannon C, Weaver W. (1977). The Mathematical Theory of Communication in: The Process and Effects of Mass Communication, ed. W. Schram and D. F. Roberts, 412-428. Illinois: University of Illinois Press.
} 
(komunikan), yang punya tujuan mendapatkan reaksi (feedback). ${ }^{2}$

Manusia adalah mahluk yang tidak sempurna (paling lemah) dalam berkomunikasi. Beberapa kondisi seperti salah dengar, salah tangkap, salah mengerti adalah bukti nyata yang menunjukan betapa kesalahan komunikasi justru terjadi dalam kontak sosial manusia dan bukan pada mahluk lainnya. Sering sekali ketidak sempurnaan ini melahirkan konflik, dan pada saat persoalan komunikasi ini diiikuti oleh perbedaan kepentingan dan kebutuhan, maka konflik akan semakin sulit untuk diselesaikan.

Komunikasi dan segala persoalannya sudah cukup banyak menginspirasi literatur studi resolusi konflik. ${ }^{3}$ Apa yang mendapat penekanan disini adalah betapa sulitnya seseorang untuk mengkomunikasikan hal yang begitu kompleks, terlebih lagi dalam keadaan emosi dan dalam situasi yang sulit. Maka dari itu tidaklah berlebihan kalau ditenggarai bahwa kelemahan komunikasi, emosi, dan perasaan tertekan akan bermuara pada situasi komunikasi yang serba salah. $^{4}$

2 Amuseghan Sunday Adejimola, Language and communication in conflict resolution Department of Arts Education,Adekunle Ajasin University, Akungba-Akoko, Journal of Law and Conflict Resolution Vol. 1(1), pp. 001-009, June, 2009

${ }^{3}$ Lihat Misalnya, Edward T. Hall. 1959. The Salient Language. Garden City. New York. Doubleday. Lihat juga, Raymond Cohen. 1991. Negotiating Across Culture; Communication Obstacles in International Diplomacy. Washington DC. USIP. Press. pp. 25-27

${ }^{4}$ Alan C. Tidwell, 1998. Conflict Resolved?: A Critical Assessment of Conflict Resolution, London, New York: Pinter Books. Hal. 86-99.
Konflik terjadi karena orang biasanya merasa bahwa dia sudah mengkomunikasikan segala hal dengan baik padahal kenyataannya tidak. Komunikasi menjadi semakin sarat dengan persoalan pada saat diikuti dengan beberapa faktor yang juga menghambat terjalinya komunikasi dengan baik seperti gender, Budaya, usia, status, dan lingkungan. Disadari atau tidak manusia sering berkomunikasi dengan dasar persepsi yang tidak lengkap informasi dan pengalaman pribadinya, yang pada akhirnya hanya akan melahirkan stereotype dan mengambil keputusan dari pengalaman interaksi sebelumnya. Lebih disayangkan lagi sering kita mengambil keputusan untuk menyelesaikan persoalan (konflik) tanpa adanya pemahaman yang mendalam. ${ }^{5}$

Paper ini akan mencermati dua pokok bahasan yang nantinya akan mendeskripsikan posisi dan peran dialog dalam meretas jalan perdamaian dengan studi kasus di Papua. Bagian awal dari tulisan ini memprioritaskan pembahasan pencarian pemahaman yang komprehensif mengenai dialog. Kemudian pada bagian kedua pembahasan akan difokuskan pada keterkaitan dialog dengan Resolusi KonflikInteraktif (RKI).

\section{Dialog: Apa yang Kita Pahami?}

Dialog bisa dipandang sebagai sebuah alat bagaimana kita menghadapi dan

\footnotetext{
${ }^{5}$ Bernard, Mayer. 2000. The Dynamics Of Conflict Resolution: A Practitioner's Guide, San Francisco, Josey-Bass, A. Wiley Company.
} 
menyelesaikan konflik secara konstruktif, ${ }^{6}$ maka dari itu respon yang umum terhadap konflik yang sudah bereskalasi menuju kekerasan adalah tuntutan dari banyak pihak untuk segera diadakan dialog, yang secara umum dipahami sebagai pertukaran dan diskusi mengenai ide-ide, yang disampaikan secara jujur dan terbuka sebagai pranata untuk menuju hubungan yang harmoni dan kesaling pemahaman. ${ }^{7}$ Hal ini mengindikasikan bahwa kesalahpahaman adalah sumber utama dari konflik, eskalasinya atau dua duanya. Kemudian bagaimana komunikasi ditingkatkan adalah langkah utama bagaimana eskalasi konflik bisa dihentikan dan diselesaikan. Dalam pembahasan ini, pertanyaan sangat sederhana yaitu apakah yang dimaksud dengan dialog? Sebuah kata yang sering digunakan dan diberikan makna yang berbeda oleh orang dan dalam kondisi yang berbeda. Dalam panggung politik misalnya kita membaca berita 'Obama Calls for 'Strong Dialogue'. ${ }^{\circ}$ Kemudian koreografer dari La Danse: The Paris Opera Ballet,$^{9}$ menegaskan bahwa pementasan yang mereka lakukan akan menciptakan dialog melalui bahasa tubuh.

\footnotetext{
${ }^{6}$ Karl-Otto Apel. 1990. Diskurs Und Verantwortung, Frankfurt Suhrkamp. Dalam Norbert Ropers. 2003. From Resolution to Transformation: The Role of Dialogue Projects. Berghof Research Center for Constructive Conflict Management.

${ }^{7}$ Ronald J. Fisher, 1997. Interactive Conflict

Resolution. Syracuse University Press. Hal. 121.

${ }^{8}$ Edward Wong dan Helenne Cooper, In Beijing, Obama Calls for 'Strong Dialogue'. The New York Times, Nove 16, 2009.

${ }^{9}$ A. O. Scoot, La Danse: The Paris Opera Ballet. The New York Times, Nove 6, 2009.
}

Secara etimologi, kita bisa mendapatkan petunjuk mengenai apa yang dimaksud dengan dialog. Asal usul nya adalah kata Yunani “dialogos", 'dia' yang berarti melalui (through) dan 'logos' yang berarti 'makna-kata' (word) dengan demikian secara asal usul kata dialog berarti melalui makna kata. Dengan demikian dialog adalah makna yang mengalir kepada kita ${ }^{10}$ Seperti apa yang sudah dirangkum oleh William Isaacs (1999), ada empat kapasitas yang harus dikembangkan sebagai landasan berperilaku dalam sebuah dialog. Pertama, penyampaian (voicing): berkenaan dengan berbicara kebenaran sesuai dengan otoritas seseorang. Pertanyaan yang harus dijawab disini adalah: apa yang harus diungkapkan? Mendengarkan (listening) dalam pengertian disini semua harus mendengarkan tanpa melakukan bantahan apa yang dikatakan oleh pihak lain atau mengiterupsi; ini mencerminkan jawaban terhadap pertanyaan apa yang dirasakan? Hormat (respecting) ini berkenaan dengan kesadaran dan pengenalan dari integritas posisi orang lain yang sangat sulit untuk dipahami secara menyeluruh; pertanyaan disini adalah bagaimana semua ini bisa cocok dengan pandangan saya? Suspending mengacu pada “menempatkan atau memegang' asumsi kita, keputusan dan kenentuan. Ini melibatkan

\footnotetext{
${ }^{10}$ David Bohm, 2004. On Dialogue, diedit oleh Lee Nichol, New York, Rout ledge Classic.
} 
pertanyaan: Bagaimana semua ini bisa berjalan ${ }^{11}$

Secara paradigmatik, dialog memberi penekanan pada kolaborasi dari sebuah proses atau aktivitas komuniksi. Dalam dialog komunikasi diposisikan sebagai mekanisme saling melengkapi dari semua partisipan yang berkolaborasi untuk mencapai sebuah tujuan dari komunikasi. Lebih jauh lagi apa yang menjadi inti dalam dialog adalah "situasi sosial" yang didapat dari sebuah lingkungan dimana interaksi itu berlangsung dan makna yang dihasilkan hanya bisa dipahami kalau dia dikaitkan dengan konteks lingkungan dimana dia dilahirkan. ${ }^{12}$ Jay Rothman memberikan penggambaran bahwa paling tidak ada empat jenis dialog yang ada dan sering dipraktekan dalam meretas jalan perdamaian di wilayah konflik.

Yang pertama adalah Posisi (Positional) dialog: para pihak yang terlibat konflik mengartikulasikan pandangan dan pendapat. Mereka bertemu bersama-sama dengan fasilitator untuk berbicara, akan tetapi pembicaraan berlangsung dalam keadaan yang berhadaphadapan (saya benar dan anda salah) persis mencerminkan konflik yang terjadi. Dalam diaog ini para pihak yang berkonflik terlibat dalam posisi tawar menawar mereka dan saling menyalahkan atas konflik yang terjadi satu sama yang lainnya. Secara literatur studi konflik, ini

\footnotetext{
${ }^{11}$ William Isaacs, 1999. Dialogue and the Art of Thinking Together, New York Doubleday, Random House.

${ }^{12}$ Herbert. H. Clark. 1996. Using Language. Cambridge. Cambridge University Press.
}

sering disebut sebagai fase yang fokus pada formulasi dari pandangan dan pendapat yang berbeda dari beragam pihak (jika memungkinkan), melindungi kesaling pemahaman terhadap segala perbedaan, dan akan dijadikan substansi identifikasi dari konflik.

Kedua adalah apa yang dinamakan Human Relations Dialogue: disini para pihak yang berkonflik difasilitasi untuk mengeksplorasi pikiran mereka mengenai konflik dan hubungan mereka dengan yang lainnya. Mereka disini harus melepas semua bentuk stereotype, mulai menyelami bahwa orang lain adalah bagian darinya bahkan menempatkan orang lain sebagai sahabat. Mereka mulai membangun rasa kepercayaan dan pemahaman terhadap orang yang terlibat dalam proses, meskipun mereka masih memiliki ketidak sepakatan mengenai isu utama dalam konflik. Menjadi fokus utama disini adalah penyebab terjadinya kesalah pahaman, dan sikap strereotype yang selalu meningkat antar pihak yang konflik. Tujuan yang ingin dicapai disini adalah terjadinya saling pengertian, meningkatnya rasa saling menghargai antar pihak. Dengan demikian, apa yang menjadi kebutuhan (needs), ketakutan dari pihak, nilai, harapan dan pengalaman selama konflik menjadi terbuka dan dipahami.

Tipe ketiga adalah dialog aktivis (activist dialogue): disini sudah ada langkah kedepan. Subyek dari isu sudah diseleksi dan dianalisis untuk nantinya dijadikan dasar titik temu untuk selanjutnya dijadikan pijakan bagaimana pihak 
yang konflik mau merubah pertentangan mereka menjadi aksi bersama. Intinya disini adalah membangun atau menyediakan fondasi bagi aksi yang akan diambil para pihak yang berkonflik disini berkumpul bersama-sama untuk membangun sebuah kondisi yang disimbolkan sebagai sebuah kota (tempat) yang hancur lebur sebagai akibat dari sebuah konflik. Kedua pihak yang bertikai disini harus melakukan hal mulia dimana mereka harus memberikan pertolongan terhadap yang terluka dan sakit sebagai korban dari konflik. Dalam situasi dialog seperti ini apa yang ingin dibangun adalah sebuah kesadaran dimana penghancuran jauh lebih gampang dilakukan daripada rekonstruksi dan rekonsiliasi konflik. Dengan kalimat sederhana, tujuan utama dialog disini adalah tidak hanya pembicaraan dan pemahaman, tapi sudah sampai pada tingkatan saling kerjasama dan bagaimana memberikan bantuan.

Tipe keempat dari dialog adalah apa yang dalam studi resolusi konflik dinamakan problem solving dialogue. Dalam prakteknya ini juga sering dinamakan sebagai problem solving workshop. Pihak yang berkonflik mengorganisasi komunikasi mereka sedemikian rupa sehingga mereka bisa menuju pada substansi apa sebenarnya yang membuat mereka berkonflik. Disini dialog harus menyertakan semua pihak yang terlibat dalam konflik untuk megekplorasi perasaan mereka mengenai konflik dan pandangan mereka terhadap pihak yang lainnya (seperti dalam human relations dialogue), akan tetapi ada fokus utama disini terhadap apa yang menjadi kebutuhan utama (human needs) dari pihak yang terlibat konflik. Human need ini biasanya adalah sumber utama dari berlangsungnya sebuah konflik. Disini usaha intensif dilakukan untuk memberikan kerangka dari konflik untuk sama sama memperhatikan kebutuhan utama, kemudian dilanjutkan dengan penyelesaian bersama (joint problem solving) untuk semakin meningkatkan jalan menuju pemenuhan kebutuhan semua pihak, yang pada akhirnya akan menjadi formula penyelesaian konflik. $^{13}$

Empat kapasitas dan tipe dialog diatas mengindikasikan bahwa dialog jelas memiliki perbedaan dengan beberapa terminologi (sinonim) seperti diskusi, debat, dan percakapan, yang sering dipadankan akan tetapi bukan dialog. Dalam diskusi, perhatian biasanya hanya untuk mendengarkan dan diikuti keinginan untuk bereaksi, menunggu momen dan menyampaikan pemikiran silih berganti. ${ }^{14}$ Sementara dalam perdebatan, yang terjadi adalah bukan mendengarkan apa yang menjadi poin utama tapi bagaimana memberikan bantahan dan sanggahan dan menjadi pemenang. Sementara diskusi adalah dimana dua pihak atau lebih menyampaikan pemikiran yang berbeda dan mempertahankannya sebagai sarana untuk melakukan analisis yang berguna bagi

\footnotetext{
13 Jay Rothman 1998. "Dialogue in Conflict: Past and Future”. Dalam Eugene Weiner 1998 (editor). The Handbook of Interethnic Coexistence, New York Continuum. Hal. 216-235.

${ }^{14}$ Michael Kahn. 1981. The Seminar: An Experiment on Humanistic Education. Journal of Humanistic Psychology. No. 21. 119-127.
} 
keseluruhan situasi dan akhirnya menuju pada suatu kesimpulan.

Meskipun ada sedikit kemiripan terutama diskusi, dialog tidaklah sama dengan keempat sinonimnya yang sudah dijabarkan secara singkat diatas. Dialog biasanya menampilkan perbedaan pandangan sebagai alat untuk menemukan pandangan yang baru, biasanya didahului dengan eksplorasi mengenai isu yang kompleks. Dengan demikian secara sederhana dialog mengedepankan perbedaan tidak hanya terfokus pada persetujuan tapi memberi ruang yang sangat luas pada ekplorasi mengenai beragam isu. ${ }^{15}$

\section{Dialog dalam Resolusi Konflik yang Interaktif}

Keberhasilan sebuah dialog harus mengikutsertakan terbangunnya kembali harmonisasi hubungan yang memungkinkan pihak-pihak yang bertikai untuk sampai pada sebuah pemahaman yang terbaik mengenai konflik dimana mereka terlibat. ${ }^{16}$ Lebih jauh lagi, Galtung mencatat bahwa penyelesaian sebuah konflik akan sangat tergantung dari bagaimana atau sejauh mana mekanisme dialog yang dilakukan mampu mempenetrasi sumber utama dari konflik. Lebih jauh lagi Galtung juga mencatat sisi lain pentingnya dialog adalah

\footnotetext{
${ }^{15}$ Nurette L. Brenner. 2011. The Field beyond Wrong Doing and Right Doing: A study of Arab-Jewis Grassroot Dialogue Group in the United States. Dissertation, Department of Organizational Behavior. Case Western Reserve University. Hal. 27-28.

${ }^{16}$ Deborah Kolb. 1994. The Reality of Making Talk Work, When Talk Work: Profiles of Mediators. Jossey Brass. Hal. 459.
}

menciptakan suasana dimana pihak yang terlibat konflik bisa saling bertemu antar satu dengan yang lainya. ${ }^{17}$ Pandangan lain juga menarik untuk diperhatikan bahwa melalui dialogu akan terjalin komunikasi yang baik (konstruktif), dengan demikian akan menuju pada pertemuan perasaan, ketika perasaan sudah bertemu maka mereka tidak hanya bertukar fakta, tapi juga mentransformasi, membangun untuk kemajuan dan kebaikan bersama.

Dialog bukan hanya sekedar komponen penting dari negosiasi, sebagai jalan menuju resolusi konflik dialog memberikan kesadaran kepada kita dan semua pihak yang terlibat konflik bagaimana menjadi pendengar yang baik. Kesalahan komunikasi manusia karena, mereka hanya pembicara yang lantang tapi belum pernah menjadi seorang pendengar yang baik, setia, dan empati. Mendengar akan meningkatkan pemahaman terhadap perbedaan budaya, nilai, dan norma yang akan menjadi pijakan utama menuju penyelesaian konflik. $^{18}$ Dengan pengandaian bisa dikatakan bahwa dialog digunakan tidak saja untuk memperbaiki mekanisme yang ada tapi bisa untuk menciptakan mekanisme yang baru seperti diilustrasikan oleh Norbert Ropers dengan dialog kita akan mendapatkan:

.....peningkatan hubungan, terbukanya kemungkinan menuju kesaling

\footnotetext{
${ }^{17}$ Johan Galtung. 2004. Saturday: Transcend and Transformed: An Introduction to Conflict Works. England, Pluto Press. Hal. 46.

18 Jeanne. M. Brett, 2007. Social Dilemmas, Negotiating Globally: How to Negotiate, Deals, Resolve Disputes, and Make Decisions across Cultural Boundaries. Springer Verlag. Hal. 231.
} 
pemahaman, menentukan dan menyadari apa peran bagi pihak yang terlibat dalam konflik, dan adanya kesempatan untuk membuka pemikiran baru untuk masa depan dari penyelesaian konflik. ${ }^{19}$

Sukses tidaknya sebuah pelaksanaan dialog, kalau mengikuti pemikiran Chris Mitchel $^{20}$ bisa dievaluasi dalam tiga tingkatan.

1. Dampaknya terhadap orang yang terlibat (perubahan pada sikap, pola baru perilaku)

2. Output, dalam hal ide-ide, saran, penilaian praktis yang nantinya disertakan dalam proses formasi tujuan.

3. Dampak jangka panjang terhadap konflik secara keseluruhan.

Dalam ketiga tingkatan berhasil atau tidaknya sebuah dialog bisa dilihat dengan membuat perbandingan situasi sebelum dan setelah dilakukanya dialog. Untuk tingkat perserta apa yang bisa dijadikan acuan tuntuk sebuah keberhasilan adalah jika terjadi perubahan persepsi mengenai konflik yang dialami, sejauh mana rasa saling memahami semakin mengalami peningkatan dan diikuti sebuah proses dimana ada kesepakatan untuk tindakan pada masa yang akan datang. ${ }^{21}$

Sebagai salah satu alat intervensi dalam resolusi konflik, dialog yang biasanya menyertakan pemaparan sejarah dan praktek

\footnotetext{
${ }^{19}$ Robert Nopers, 2003. From Resolution to Transformation: The Role of Dialogue Projects. Berghof Research Center for Constructive Conflict Management.

${ }^{20}$ Christopher Michell dan Michael Banks, 1996. Handbook of Conflict Resolution: The analytical Problem Solving Apparoach. Pinter, Wellington House. London. Hal. 152.

${ }^{21}$ Christopher Michell dan Michael Banks, 1996. ibid. Hal. 153.
}

mendengarkan yang aktif diklaim bahwa jika berhasil akan membawa konflik yang tadinya destruktif bisa ditransformasi menjadi konflik yang konstruktif dengan beberapa ciri sebagai berikut:

1. Ada kejelasan, definisi, dari persoalan yang dihadapi.

2. Tidak lagi menutupi apa yang menjadi kepentingan dan kebutuhan.

3. Menemukan dan memprioritaskan pilihan

4. Menuju pada pelaksanaan caracara damai (dialog baru)

5. Meningkatkan kesaling pemahaman. ${ }^{22}$

Sebagai sebuah model dalam mempenetrasi konflik, kalau menggunakan istilahnya Ronald J. Fisher, dialog sering mendapatkan tempat dalam mekanisme "Interactive Conflict Resolution". Para ahli konflik ternama yang menempatkan metode dialog dalam mekanisme resolusi konflik adalah John Burton, pendiri dari pusat analisis konflik di College University, London, yang mengorganisir 'control communication' workshop yang memfokuskan pada konflik Indonesia-Malaysia dan Siprus, pada pertengahan tahun 60-an. Herbert Kelman dari Universitas Harvard yang mengembangkan pendekatan interaksi (interactional approach) dari 'problem solving Workshop' bersama sama dengan Stephen Cohen, Edward Azar, yang memfokuskan pada konflik di Timur Tengah. Kemudian Leonard Doob yang juga

\footnotetext{
${ }^{22}$ Linda L. Putnam. Communication and Conflict Resolution, Department of Communication University of California, Santa Barbra.
} 
mengembangkan mekanisme workshop untuk pengelolaan konflik konflik di Afrika.

Kelompok ahli dengan mekanisme yang dikembangkan seperti disebut diatas dalam perkembangan studi resolusi konflik sering disebut sebagai (interactive conflict resolution) resolusi konflik yang interaktif selanjutnya (RKI) karena memberikan bobot pada efektifitas dan interaksi berhadap hadapan yang konstruktif antar para perwakilan pihak yang berkonflik sebagai jalan penyelesaian baik konflik internal maupun internasional. Dalam artian yang sempit, RKI didefinisikan sebagai melibatkan kelompok kecil, diskusi penyelesaian masalah antar perwakilan tidak resmi dari kelompok identitas atau negara yang terlibat dalam konflik yang difasilitasi oleh pihak yang netral yang terdiri dari para akademisi sosial. Sementara dalam pengertian yang luas serta sebagai pegangan dalam tulisan ini RKI adalah bagaimana memfasilitasi aktifitas tatap muka dalam dialog, pelatihan, pendidikan, dan konsultasi yang mempromosikan konflik analisis yang kolaboratif dan penyelesaian masalah antar pihak yang terlibat konflik, yang nantinya mampu memenuhi human needs dan mempromosikan pembangunan perdamaian keadilan dan kesetaraan.

Asumsi utama, dalam RKI adalah analisis yang konstruktif dan penyelesaian masalah yang kreatif antar pihak yang bersengketa akan menjadi sangat baik untuk diterapkan melalui bantuan pihak ketiga yang memiliki pengetahuan dan kemampuan yang memadai. Dialog sebagai metode disini haruslah menyertakan pendekatan sosial psikologis dengan meyakinkan bahwa isu-isu hubungan seperti (kesalahpahaman, tidak terpenuhi dan selarasnya kebutuhan) harus disentuh dan konflik akan diselesaikan hanya dengan solusi yang diterima semua pihak dan yang dibangun melalui interaksi. ${ }^{23}$

\section{Catatan Penutup}

Dari sekian banyak publikasi yang sudah ada mengenai keterkaitan dialog sebagai alat intervensi dalam mengelola konflik paling tidak ada Sembilan pelajaran yang akan sangat bermanfaat bagi proses mengelolaan sebuah konflik.

Untuk sampai pada suatu ambisi penyelesaian (resolusi) sebuah konflik, hal ini hanya akan bisa dicapai melalui sebuah proses yang tentunya membutuhkan tidak hanya waktu yang relatif panjang, akan tetapi juga harus disertai juga dengan kesabaran dan niat baik semua pihak untuk sampai kepada komitmen yang menuju pada perbaikan masa depan. Hal ini tampak tidak mengada-ada karena sebuah pembangunan kepercayaan personal, kejelasan posisi, dan persepsi mengenai fakta konflik yang dialami adalah sebuah persyaratan yang harus disertakan dalam sebuah dialog. ${ }^{24}$

Proses dialog adalah permulaan untuk menuju sesuatu yang lebih baik. Dialog

\footnotetext{
${ }^{23}$ Ronald J. Fisher, 1997. Op cit. hal. 8.

${ }^{24}$ Rojer Fisher dan William Ury, 1981. Getting to Yess: Negotiating Agreement Without Giving In. Boston, Ms: Houghton Miffin.
} 
memberikan ruang terbuka bagi semua perwakilan pihak yang berkonflik untuk menjadi pahlawan demi kebaikan dimasa yang akan dating. Sebuah mekanisme resolusi yang lahir dari proses dialog akan selalu menyertakan nama dan tempat dialog tersebut dilaksanakan.

Tantangan terbesar dalam proses sebuah dialog adalah bagaimana menjamin penguasaan terhadap metode fasilitasi dan teknik berkomunikasi. Hal yang pertama berkaitan dengan persiapan, tunjangan keuangan, dan tempat dimana dialog tersebut akan dilaksanakan. Penentuan dimana dialog akan dilaksanakan adalah kekuatan dan sekaligus kelemahan dari dialog tersebut, karena tempat yang netral akan menjadi kekuatan dan jika tempatnya tidak imparsial maka dialog pun membuka ruang untuk menuai kegagalan.

\section{Daftar Pustaka}

Adejimola, Amuseghan Sunday, Language and communication in conflict resolution Department of Arts Education,Adekunle Ajasin University, Akungba-Akoko, Journal of Law and Conflict Resolution Vol. 1(1), pp. 001-009, June, 2009

Apel. Karl-Otto 1990. Diskurs Und Verantwortung, Frankfurt Suhrkamp. Dalam Norbert Ropers. 2003. From Resolution to Transformation: The Role of Dialogue Projects. Berghof Research Center for Constructive Conflict Management.

Brenner. L. Nurette 2011. The Field beyond Wrong Doing and Right Doing: A study of Arab-Jewis Grassroot Dialogue Group in the United States. Dissertation, Department of Organizational Behavior. Case Western Reserve University.
Bohm, David 2004. On Dialogue, diedit oleh Lee Nichol, New York, Rout ledge Classic.

Brett, M. Jeanne. 2007. Social Dilemmas, Negotiating Globally: How to Negotiate, Deals, Resolve Disputes, and Make Decisions across Cultural Boundaries. Springer Verlag.

Clark. H. Herbert. 1996. Using Language. Cambridge. Cambridge University Press.

Cohen, Raymond. 1991. Negotiating Across Culture; Communication Obstacles in International Diplomacy. Washington DC. USIP. Press.

C. Shannon, Weaver W. (1977). The Mathematical Theory of Communication in: W. Schram and D. F. Roberts. The Process and Effects of Mass Communication., Illinois: University of Illinois Press.

Fisher, J. Ronald 1997. Interactive Conflict Resolution. Syracuse University Press.

Fisher, Rojer dan William Ury, 1981. Getting to Yess: Negotiating Agreement Without Giving

Galtung. Johan. 2004. Saturday: Transcend and Transformed: An Introduction to Conflict Works. England, Pluto Press.

Hall T. Edward. 1959. The Salient Language. Garden City. New York. Doubleday.

Isaacs, William 1999. Dialogue and the Art of Thinking Together, New York Doubleday, Random House.

Kahn. Michael 1981. The Seminar: An Experiment on Humanistic Education. Journal of Humanistic Psychology. No. 21. 119-127.

Kolb, Deborah. 1994. The Reality of Making Talk Work, When Talk Work: Profiles of Mediators. Jossey Brass.

Mayer. Bernard, 2000. The Dynamics Of Conflict Resolution: A Practitioner's Guide, San Francisco, Josey-Bass, A. Wiley Company.

Michell, Christopher dan Michael Banks, 1996. Handbook of Conflict Resolution: The analytical Problem Solving Apparoach. Pinter, Wellington House. London.

Nopers, Robert 2003. From Resolution to Transformation: The Role of Dialogue 
Projects. Berghof Research Center for Constructive Conflict Management.

Putnam. L. Linda Communication and Conflict Resolution, Department of Communication University of California, Santa Barbra.

Rothman Jay 1998. "Dialogue in Conflict: Past and Future". Dalam Eugene Weiner 1998 (editor). The Handbook of Interethnic Coexistence, New York Continuum.
Scoot A. O., La Danse: The Paris Opera Ballet. The New York Times, Nove 6, 2009.

Tidwell C. Alan 1998. Conflict Resolved?: A Critical Assessment of Conflict Resolution, London, New York: Pinter Books.

Wong Edward dan Helenne Cooper, In Beijing, Obama Calls for 'Strong Dialogue'. The New York Times, Nove 16, 2009. 